\title{
Feasibility of Using Biocontainers in a Pot-in-pot System for Nursery Production of River Birch
}

\author{
Tongyin $\mathrm{Li}^{1}$, Guihong $\mathrm{Bi}^{1,5}$, Genhua Niu ${ }^{2}$, Susmitha S. Nambuthiri ${ }^{3}$, \\ Robert L. Geneve ${ }^{3}$, Xueni Wang ${ }^{4}$, R. Thomas Fernandez ${ }^{4}$, \\ Youping Sun ${ }^{2}$, and Xiaojie Zhao ${ }^{1}$
}

\begin{abstract}
AdDITIONAL INDEX wORDs. PIP, sustainability, plant growth, water use, Betula nigra
\end{abstract}
SUMmARY. The performance of biocontainers as sustainable alternatives to the traditional petroleum-based plastic containers has been researched in recent years due to increasing environmental concern generated by widespread plastic disposal from green industry. However, research has been mainly focused on using biocontainers in short-term greenhouse production of bedding plants, with limited research investigating the use of biocontainers in long-term nursery production of woody crops. This project investigated the feasibility of using biocontainers in a pot-in-pot (PIP) nursery production system. Two paper (also referred as wood pulp) biocontainers were evaluated in comparison with a plastic container in a PIP system for 2 years at four locations (Holt, MI; Lexington, KY; Crystal Springs, MS; El Paso, TX). One-year-old river birch (Betula nigra) liners were used in this study. Results showed that biocontainers stayed intact at the end of the first growing season, but were penetrated to different degrees after the second growing season depending on the vigor of root growth at a given location and pot type. Plants showed different growth rates at different locations. However, at a given location, there were no differences in plant growth index (PGI) or plant biomass among plants grown in different container types. Daily water use (DWU) was not influenced by container type. Results suggest that both biocontainers tested have the potential to be alternatives to plastic containers for short-term ( 1 year) birch production in the PIP system. However, they may not be suitable for long-term (more than 1 year) PIP production due to root penetration at the end of the second growing season.

$\mathrm{T}$ he widespread use and disposal of petroleum-based plastic containers in the green industry has generated serious concerns (Evans and Hensley, 2004; Hall et al., 2009; Levitan and Barros, 2003). Biocontainers are containers made of biodegradable or compostable materials from plant and animal waste to degradable by-products from various industries

This project was supported by the USDA National Institute of Food and Agriculture-Specialty Crops Research Initiative Grant program with matching resources from Michigan State University, University of Kentucky, Mississippi State University, and Texas A\&M System. Hatch project numbers include MICL02010, KY011032, MIS211090, and TEX09045.

The authors appreciate the in-kind support of substrate and containers from Renewed Earth LLC, Kalamazoo, MI, and biocontainers from Western Pulp Products Co., Corvallis, OR.

${ }^{1}$ Department of Plant and Soil Sciences, Mississippi State University, Mississippi State, MS 39762

${ }^{2}$ Texas A\&M AgriLife Research and Extension Center at El Paso, Texas A\&M System, 1380 A\&M Circle, El Paso, TX 79927

${ }^{3}$ Department of Horticulture and Landscape Architecture, University of Kentucky, Lexington, KY 40516

${ }^{4}$ Department of Horticulture, Michigan State University, 1066 Bogue Street, East Lansing, MI 48824

${ }^{5}$ Corresponding author. E-mail: gbi@pss.msstate.edu.
(Hall et al., 2010; Nambuthiri et al., 2015a; White, 2009). A variety of biocontainers, such as peat, manure, paper, and straw, have been studied in recent years as potential alternatives to traditional plastic containers.

Biocontainers may increase, decrease, or have no effect on plant growth, depending on plant species or container type (Beeks and Evans, 2013a; Evans and Hensley, 2004; Koeser et al., 2013b; Kuehny et al., 2011). 'Score Red' geranium (Pelargonium xhortorum) and 'Grape Cooler' vinca (Catharanthus roseus) had greater shoot growth when they were grown in 5 -inch plastic containers than being grown in bioplastic or rice straw containers (Kuehny et al., 2011). 'Rainier
Purple' cyclamen (Cyclamen persicum) plants had higher dry root weights when grown in paper and wood fiber containers than those grown in plastic containers (Beeks and Evans, 2013a). For some plant species, for example 'Dazzler Lilac Splash' impatiens (Impatiens wallerana), its root or shoot growth was similar among all tested container types [plastic, paper, rice hull, peat, coconut fiber, composted dairy manure, Fertil $(80 \%$ cedar fiber, $20 \%$ peat; Fertil International, Boulogne-Billancourt, France), and bioplastic] (Kuehny et al., 2011). Regardless of the difference in growth, Kuehny et al. (2011) found that all the tested containers can produce quality commercial plants of geranium and vinca for retail or landscape uses, consistent with results indicating that 'Florida Sun Jade' coleus (Solenostemon scutellarioides) plants grown in biocontainers were of equal size and quality as those grown in plastic containers under a certain irrigation type (Koeser et al., 2013a).

Biocontainers have varying materialderived water consumption characteristics compared with traditional plastic containers due to the distinctive hydrophilic or hydrophobic characteristics of sidewall materials (Evans and Karcher, 2004; Koeser et al., $2013 b$ ). By comparing water use of bedding plants like vinca, impatiens, and 'Yellow Madness' petunia (Petunia $\times$ bybrida) in various container types (plastic, bioplastic, peat, manure, rice hull, straw, wood fiber, coir, and poultry feather), it was reported that the effect of container type was significant among containers on both water loss per container and total water consumption (Evans et al., 2010; Koeser et al., 2013b). Plants grown in peat and feather containers required more water and more frequent irrigations than those grown in plastic containers (Evans and Karcher, 2004). Similarly, the amount of water used to produce geranium was higher and the average intervals of irrigation

\begin{tabular}{llll}
\hline $\begin{array}{l}\text { Units } \\
\text { To convert U.S. to SI, } \\
\text { multiply by }\end{array}$ & U.S. unit & SI unit & $\begin{array}{l}\text { To convert SI to U.S., } \\
\text { multiply by }\end{array}$ \\
\hline 3.7854 & gal & $\mathrm{L}$ & 0.2642 \\
2.54 & inch $(\mathrm{es})$ & $\mathrm{cm}$ & 0.3937 \\
25.4 & inch $(\mathrm{es})$ & $\mathrm{mm}$ & 0.0394 \\
28.3495 & $\mathrm{Oz}$ & $\mathrm{g}$ & 0.0353 \\
$\left({ }^{\circ} \mathrm{F}-32\right) \div 1.8$ & ${ }^{\circ} \mathrm{F}$ & ${ }^{\circ} \mathrm{C}$ & $\left({ }^{\circ} \mathrm{C} \times 1.8\right)+32$
\end{tabular}

\footnotetext{
Hortlednology $\cdot$ February $201525(1)$
} 
were shorter when using peat, Fertil, coconut fiber, composted dairy manure, and rice straw containers than using traditional plastic containers (Evans et al., 2010).

Compared with efforts to evaluate the influence of biocontainers on water use and plant growth of bedding plants in greenhouse production, there has been limited research regarding performance of woody nursery crops in biocontainers and no studies associated with PIP production systems. One of the known advantages of a PIP system in nursery production is that it prevents blow-over of the plants because pots are planted in-ground and protects overwinter plants from cold injury without any overwintering structure requirement. The PIP system was reported to increase root growth and uniformity of root systems for some landscape plants, possibly by lowering substrate temperature during growing season (Ruter, 1993).

Compared with field production, irrigation management is crucial with a PIP production system since plant roots cannot spread outside the socket pot (outside pot to provide sufficient stiffness and strength to prevent the soil from compressing and pinching the two containers together) into the ground to absorb surrounding water. Appropriate irrigation practice in a PIP system was proven to increase irrigation efficiency and longevity of slow-release fertilizer (Ruter, 1998; Zhu et al., 2005). Zhu et al. (2005) applied a new irrigation system (with micro spray stakes, drainage water measurement devices, container-substrate moisture probes, a weather station, and data loggers) in PIP production of Red Sunset maple (Acer rubrum 'Franksred'), and they found that it not only helped reduce water use but also improved nutrient use efficiency by having closer monitoring over moisture level of the substrate.

A concern with the application of biocontainers in PIP system is root escape from the production pot (the inside pot that hold the plant), especially with plants that have vigorous root growth. Root growing out of the production pot through the drainage hole can cause problems with harvesting when the socket pots are often destroyed. Degradation of the container wall is also impacted by irrigation practices, temperature, container material, etc. (Lopez and Camberato, 2011). Evans et al. (2010) reported that biocontainers made from different materials have varying dry and wet strength. With containers able to absorb water into the container wall, their strength decreased when wet (Evans et al., 2010; Koeser et al., $2013 \mathrm{~b})$. In order for biocontainers to be used to produce woody plants that have a longer production period, they have to stay intact long enough through the production cycle without being penetrated by roots and be able to withstand mechanical handling in the subsequent processes of harvesting and shipping (Koeser et al., 2013a). The objectives of this study are to evaluate the mechanical performance of two paper biocontainers in a PIP production system and to investigate how biocontainers affect plant growth and water use of river birch.

\section{Materials and methods}

EXPERIMENT SETUP. The study was conducted from June 2011 through Oct. 2012 at four locations: Michigan State University, Holt [lat. $42^{\circ} 43^{\prime} \mathrm{N}$, long. $84^{\circ} 33^{\prime} \mathrm{W}$; U.S. Department of Agriculture (USDA) Plant Hardiness Zone 5b], University of Kentucky Horticulture Teaching and Research Center, Lexington (lat. $37^{\circ} 58^{\prime} \mathrm{N}$, long. $84^{\circ} 32^{\prime} \mathrm{W}$; USDA Plant Hardiness Zone 6b), Mississippi State University Truck Crops Branch Experiment Station, Crystal Springs (lat. $31^{\circ} 59^{\prime} \mathrm{N}$, long. $90^{\circ} 21^{\prime} \mathrm{W}$; USDA Hardiness Plant Zone 8a), and Texas A\&M AgriLife Research and Extension Center at El Paso, El Paso (lat. $31^{\circ} 41^{\prime} \mathrm{N}$, long. $106^{\circ} 16^{\prime} \mathrm{W}$; USDA Hardiness Plant Zone 8a) (USDA, 2012). One-year-old bare root liners of river birch were planted into three types of 7 -gal production containers in mid-June 2011. There were two paper (also referred as wood pulp) biocontainers made from recycled paper: KF (Kord Fiber Grow FNP15140; ITML Horticultural Products, Middlefield, $\mathrm{OH}$ ) and WP (15 × 13 RD; Western Pulp Products Co., Corvallis, OR) (Table 1). A conventional plastic container (GL 2800; Nursery Supplies, Chambersburg, PA) was used as control (Table 1). The production container was filled with a substrate of 85 pine bark: 15 peat (by volume) (Renewed Earth, Kalamazoo, $\mathrm{MI})$. Production containers with birch liners were then placed into a 15-gal plastic socket pot (GL6900, Nursery Supplies) (Table 1). The gap existing between the production and socket pots was sealed with bubble wrap. Copper treated $18 \times 18$-inch fabric squares (Textel SpinOut; A.M. Leonard Co., Piqua, $\mathrm{OH}$ ) were placed between each production and socket pot to prevent root escape from the production pot and rooting into the soil (Ruter, 1994). The ground was covered with nursery fabric to control weeds. Due to plant loss resulted from irrigation problems, the experiment was only conducted at Michigan and Kentucky in 2011.

Fertillzation AND IRRIGATION. Plants were fertilized soon after transplanting with $15 \mathrm{~N}-3.9 \mathrm{P}-10 \mathrm{~K}$ slow-release fertilizer (Osmocote Plus 15-9-12; Scotts, Marysville, $\mathrm{OH}$ ) at a rate of $63 \mathrm{~g}$ per container in 2011 and again fertilized at the same rate in Spring 2012. Substrate moisture content was determined with an electronic moisture probe (ML2; Dynamax, Houston, TX). Irrigation, delivered by one emitter (about $6 \mathrm{gal} / \mathrm{h}$, Tornado Ray Jet; Deere \& Co., Moline, IL), was automatically applied to replace $100 \%$ of DWU based on sensor readings. Volumetric water content readings in percentage were converted to water use volume (in liters) by multiplying pot volume. Data on DWU were only collected at Michigan and Kentucky.

Substrate temperature. Nine temperature sensors (HOBO TMC20HD; Onset Computer Corp., Bourne, MA) were randomly buried into three production pots of each container type (one sensor per pot) with a depth of 2 inches at the midpoint from pot edge to the center. Sensors recorded data every 15 min on a data logger (HOBO, Onset Computer Corp.). A weather station was installed on-site to record surrounding air temperature. Data on substrate temperature were only collected at Mississippi.

Plant growth measurements AND BIOCONTAINER INTEGRITY. Plant height was measured on a monthly interval at all locations in 2011 and at Mississippi and Texas in 2012. Plant growth index was calculated as PGI = [plant height + plant width 1 (widest points apart) + plant width 2 (width at the perpendicular direction of width 1)]/3. Plant growth index was measured at Michigan and Mississippi in 2011, and at Mississippi and Texas in 
Table 1. Container type or abbreviation, product name, composition, volume, and manufacturer of containers used in the study.

\begin{tabular}{|c|c|c|c|c|}
\hline $\begin{array}{l}\text { Container type } \\
\text { or abbreviation }\end{array}$ & Product name & Container composition & $\begin{array}{l}\text { Container } \\
\text { vol }\left(\mathrm{cm}^{3}\right)^{z}\end{array}$ & Manufacturer \\
\hline Plastic & GL 2800 & Plastic & 24,575 & $\begin{array}{l}\text { Nursery Supplies, } \\
\text { Chambersburg, PA }\end{array}$ \\
\hline Socket pot & GL 6900 & Plastic & 49,949 & Nursery Supplies \\
\hline WP & $15 \times 13 \mathrm{RD}$ & $\begin{array}{l}\text { Mix of recycled } \\
\text { paper with a binder }\end{array}$ & 24,800 & $\begin{array}{l}\text { Western Pulp Products } \\
\text { Co., Corvallis, OR }\end{array}$ \\
\hline
\end{tabular}

${ }^{2}$ Volume as indicated on manufacturer's website or catalog; $1 \mathrm{~cm}^{3}=0.0610$ inch $^{3}$.

Table 2. Plant height of river birch grown in three container types at Michigan, Kentucky, Mississippi, and Texas in Oct. 2011, and at Mississippi and Texas in Oct. 2012.

\begin{tabular}{|c|c|c|c|c|c|c|}
\hline \multirow[b]{2}{*}{ Container $^{\mathrm{z}}$} & \multicolumn{4}{|c|}{ Plant ht $2011[\text { mean } \pm S E(\mathrm{~cm})]^{\mathrm{y}}$} & \multicolumn{2}{|c|}{ Plant ht $2012[\text { mean } \pm \text { SE }(\mathrm{cm})]^{\mathrm{x}}$} \\
\hline & Michigan & Kentucky & Mississippi & Texas & Mississippi & Texas \\
\hline Plastic & $93 \pm 8.5$ & $59 \pm 4.3$ & $84 \pm 1.4$ & $65 \pm 6.0$ & $149 \pm 15$ & $90 \pm 10.0$ \\
\hline WP & $84 \pm 4.3$ & $61 \pm 5.9$ & $81 \pm 2.0$ & $63 \pm 10.5$ & $159 \pm 15$ & $91 \pm 11.9$ \\
\hline $\mathrm{KF}$ & $84 \pm 3.2$ & $62 \pm 2.3$ & $83 \pm 2.7$ & $59 \pm 7.8$ & $158 \pm 20$ & $95 \pm 15.2$ \\
\hline Significance $^{w}$ & NS & NS & NS & NS & NS & NS \\
\hline
\end{tabular}

Table 3. Plant growth index (PGI) of river birch grown in three container types at Michigan and Mississippi in Oct. 2011, and at Mississippi and Texas in Oct. 2012.

\begin{tabular}{|c|c|c|c|c|}
\hline \multirow[b]{2}{*}{ Container $^{\mathrm{z}}$} & \multicolumn{2}{|c|}{ PGI $2011[\text { mean } \pm S E(\mathrm{~cm})]^{y}$} & \multicolumn{2}{|c|}{ PGI $2012[$ mean \pm SE $(\mathrm{cm})]$} \\
\hline & Michigan & Mississippi & Mississippi & Texas \\
\hline Plastic & $70 \pm 4.8$ & $58 \pm 1.7$ & $144 \pm 11.7$ & $80 \pm 6.0$ \\
\hline WP & $60 \pm 6.3$ & $54 \pm 3.1$ & $154 \pm 13.9$ & $80 \pm 2.8$ \\
\hline $\mathrm{KF}$ & $62 \pm 7.8$ & $60 \pm 1.9$ & $156 \pm 20.8$ & $84 \pm 5.2$ \\
\hline Significance $^{\mathrm{x}}$ & NS & NS & NS & NS \\
\hline \multicolumn{5}{|c|}{$\begin{array}{l}{ }^{\mathrm{z}} \mathrm{WP}=\text { biocontainer made from a mix of recycled paper (Western Pulp Products Co., Corvallis, OR), KF = } \\
\text { biocontainer made from recycled paper (ITML Horticultural Products, Middlefield, OH). } \\
\text { y } 1 \mathrm{~cm}=0.3937 \text { inch. } \\
{ }^{x} \mathrm{NS}=\text { no significant difference among means within a column indicated by Fisher's least significant difference test at } \\
P<0.05 \text {. }\end{array}$} \\
\hline
\end{tabular}

2012. At the end of each growing season in October, a visual evaluation of the two biocontainers was conducted to assess container integrity. By the end of the second growing season in 2012, plants were destructively harvested and separated into stems and roots. Plant tissues were oven-dried at $60{ }^{\circ} \mathrm{C}$ to constant weight, and tissue dry weights were measured.

EXPERIMENTAL DESIgN AND STATISTICAL ANALYsis. This experiment was arranged at each location in a completely randomized design with eight replications (one plant/container) in each treatment (container type). Data were analyzed by analysis of variance (ANOVA) using SAS (version 9.3; SAS Institute, Cary, NC). Comparisons of means among treatments were conducted using Fisher's least significant difference test at $P<0.05$.

\section{Results}

Plant Growth. No significant differences in plant height or PGI were seen among containers tested at any of the sites in 2011 or 2012 (Tables 2 and 3). However, average plant height at Michigan and Mississippi was about $40 \%$ higher than that at Kentucky and Texas by the end of the first growing season. Average plant height at Mississippi was $69 \%$ higher than that at Texas by the end of the second growing season (Table 2 ).

Upon harvest in Oct. 2012, there were no differences in stem, root, or total dry weights of plants grown in different container types at a given location (Table 4). However, average plant stem and root dry weights at Mississippi were about four times higher than those at Texas.

Daily water use. During Aug. 2011 at Kentucky, DWU varied from 1.34 to $3.20 \mathrm{~L}$ per day depending on weather conditions (Table 5 ). No difference in DWU was found in three container types on a given day (Table 5). In the same growing season at Michigan, on the measuring dates from June to November (19 June, 30 June, 3 Aug., and 23 Nov.), there was no difference in DWU among different container types (Table 6).

Substrate temperature. Substrate temperature fluctuated as the air temperature changed (Fig. 1). However, the temperature change during a day in any container type was less dramatic than that in the air. On any 
Table 4. Plant dry weights (DW) of river birch in three container types at Mississippi and Texas in Oct. 2012.

\begin{tabular}{|c|c|c|c|c|c|c|}
\hline \multirow[b]{2}{*}{ Container $^{\mathrm{z}}$} & \multicolumn{2}{|c|}{ Stem DW $2012[\text { mean } \pm \text { SE }(g)]^{y}$} & \multicolumn{2}{|c|}{ Root DW $2012[$ mean \pm SE $(g)]$} & \multicolumn{2}{|c|}{ Total DW $2012[$ mean \pm SE $(\mathrm{g})]$} \\
\hline & Mississippi & Texas & Mississippi & Texas & Mississippi & Texas \\
\hline Plastic & $1,278 \pm 216$ & $192 \pm 18$ & $1,284 \pm 231$ & $293 \pm 38$ & $2,562 \pm 247$ & $484 \pm 133$ \\
\hline $\mathrm{KF}$ & $1,461 \pm 229$ & $234 \pm 28$ & $1,490 \pm 239$ & $330 \pm 37$ & $2,951 \pm 313$ & $564 \pm 144$ \\
\hline Significance $^{\mathrm{x}}$ & NS & NS & NS & NS & NS & NS \\
\hline
\end{tabular}

Table 5. Average daily water use (DWU) of river birch grown in three container types in Aug. 2011 at Kentucky.

\begin{tabular}{lcccc}
\hline & \multicolumn{3}{c}{ DWU $[\text { mean } \pm S E(L)]^{\mathrm{z}}$} & \\
\cline { 2 - 4 } Date & Plastic & WP & KF & Significance $^{\mathrm{y}}$ \\
\hline 2 Aug. & $1.37 \pm 0.21$ & $1.71 \pm 0.93$ & $1.34 \pm 0.23$ & NS \\
3 Aug. & $1.60 \pm 0.61$ & $2.06 \pm 0.86$ & $2.24 \pm 0.41$ & NS \\
9 Aug. & $1.35 \pm 0.69$ & $1.90 \pm 0.57$ & $2.20 \pm 0.90$ & NS \\
10 Aug. & $2.46 \pm 1.02$ & $2.69 \pm 1.12$ & $2.34 \pm 0.89$ & NS \\
11 Aug. & $1.94 \pm 0.88$ & $1.80 \pm 0.80$ & $1.89 \pm 0.87$ & NS \\
12 Aug. & $2.69 \pm 0.77$ & $2.68 \pm 1.18$ & $2.81 \pm 0.61$ & NS \\
15 Aug. & $1.68 \pm 0.52$ & $2.22 \pm 0.88$ & $2.01 \pm 0.44$ & NS \\
16 Aug. & $2.90 \pm 0.65$ & $3.19 \pm 0.79$ & $2.74 \pm 0.74$ & NS \\
17 Aug. & $3.00 \pm 0.75$ & $3.20 \pm 0.51$ & $3.11 \pm 0.65$ & NS \\
24 Aug. & $2.69 \pm 0.58$ & $2.93 \pm 0.50$ & $2.63 \pm 0.86$ & NS \\
29 Aug. & $3.15 \pm 0.53$ & $3.07 \pm 0.52$ & $3.07 \pm 0.77$ & NS
\end{tabular}

${ }^{2} \mathrm{WP}=$ biocontainer made from a mix of recycled paper (Western Pulp Products Co., Corvallis, OR), $\mathrm{KF}=$ biocontainer made from recycled paper (ITML Horticultural Products, Middlefield, OH); $1 \mathrm{~L}=0.2642$ gal.

${ }^{\mathrm{y}} \mathrm{NS}=$ no significant difference among means within a row indicated by Fisher's least significant difference test at $P<0.05$.

Table 6. Average daily water use (DWU) of river birch grown in three container types in 2011 at Michigan.

\begin{tabular}{|c|c|c|c|c|}
\hline \multirow[b]{2}{*}{ Container $^{z}$} & \multicolumn{4}{|c|}{$\mathrm{DWU}[\operatorname{mean} \pm \mathrm{SE}(\mathrm{L})]^{\mathrm{y}}$} \\
\hline & 19 June & 30 June & 3 Aug. & 23 Nov. \\
\hline Plastic & $1.81 \pm 0.98$ & $1.08 \pm 0.89$ & $1.20 \pm 1.41$ & $1.33 \pm 0.54$ \\
\hline WP & $2.61 \pm 1.29$ & $0.64 \pm 0.74$ & $0.99 \pm 1.51$ & $1.95 \pm 0.75$ \\
\hline $\mathrm{KF}$ & $2.87 \pm 0.94$ & $0.50 \pm 0.90$ & $0.77 \pm 0.80$ & $1.75 \pm 1.04$ \\
\hline Significance $^{\mathrm{x}}$ & NS & NS & NS & NS \\
\hline
\end{tabular}

given day from May 31 to Aug. 18 2012 , the maximum temperature in the substrate was lower than that in the air and the minimum temperature in the substrate was higher than that in the air (Fig. 1). There were no differences in maximum, minimum, or average temperature within a given day in the substrate among three container types (Fig. 1).

Biocontainer InTEgrity. By the end of the first growing season in 2011 , sidewalls and bottoms of the biocontainers were intact at all locations. However, by the end of the second growing season in 2012 , pots were penetrated to different degrees by root growth, with lower and bottom parts of some pots broken during the process of pulling out the plants from the PIP system. KF container $(40.3 \%$ broken in Mississippi, $30.7 \%$ in Texas) was more broken than WP $(24.2 \%$ broken in Mississippi, 20.6\% in Texas) at the end of the second growing season. Plastic containers remained intact with some roots growing out of the container through drainage holes.

\section{Discussion}

River Birch is adaptive to a variety of growing conditions, with widespread
USDA hardiness zones from 4 to 9 a (Gilman and Watson, 1993). All four locations where this study was conducted are within these USDA hardiness zones: Michigan (5b), Kentucky (6b), Mississippi (8a), and Texas (8a). Birch plants showed varying vigor of growth at different locations due to different growing environments. However, at a certain location, there was no significant difference in plant height, PGI, or dry weight among plants grown in different container types, suggesting that the difference of growth was more subject to growing environment rather than container type. Under environmental conditions at any of the four sites, using paper containers ( $\mathrm{KF}$ or WP, in this case) as the production pot in a PIP production system produced plants of similar size as traditional plastic container, consistent with results from some greenhouse studies growing bedding plants in biocontainers (Koeser et al., 2013a; Kuehny et al., 2011; Lopez and Camberato, 2011) and aboveground nursery production (Wang et al., 2015).

It was reported that containers made from hydrophilic materials, paper for instance, can result in higher water consumption by increased water loss through the container sidewall (Evans and Karcher, 2004). The biocontainers used in this study are made from mainly a mix of recycled paper, and thus can be categorized as hydrophilic containers. However, DWU of biocontainers was not significantly higher than that of traditional plastic container in this study. In contrast, Wang et al. (2015) found a significant difference in DWU in wood pulp (paper) containers in an aboveground nursery production system. This might be related to the use of two pots in the PIP system. Installed in the socket pot and planted in ground, the production pot is protected from direct exposure to 

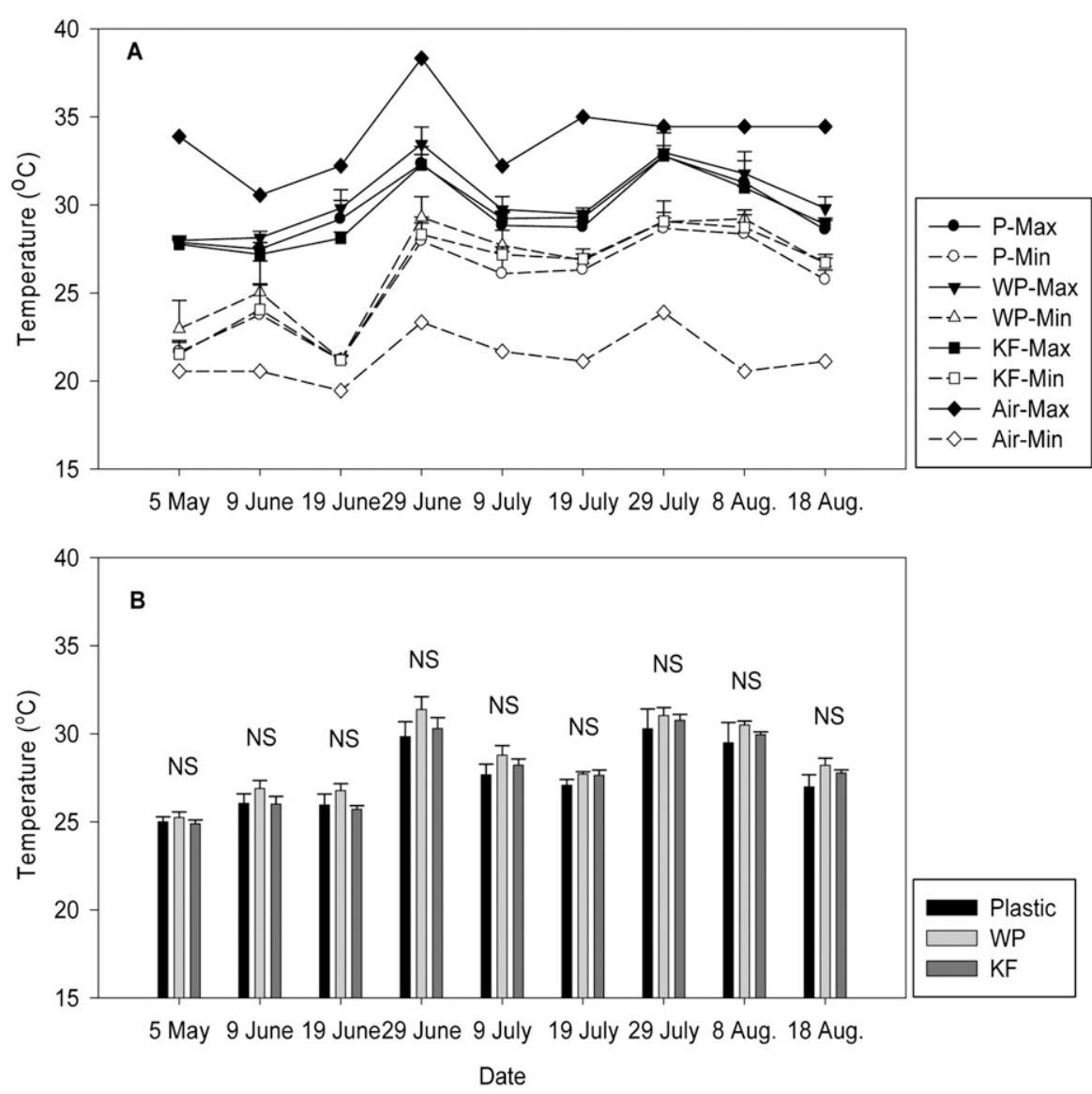

Fig. 1. (A) Daily maximum ( $\max$ ) and minimum ( $\mathrm{min})$ and (B) average substrate temperatures in three container types: Plastic $(\mathrm{P}), \mathrm{WP}$ (biocontainer made from a mix of recycled paper; Western Pulp Products Co., Corvallis, OR), and KF (biocontainer made from recycled paper; ITML Horticultural Products, Middlefield, $\mathrm{OH}$ ) in Crystal Springs, MS, in 2012. NS on top of bars suggest no difference in average substrate temperature among container types on a given day indicated by Fisher's least significant difference test at $P<0.05 ;\left(1.8 \times{ }^{\circ} \mathrm{C}\right)+32={ }^{\circ} \mathrm{F}$.

the sun and intensive water evaporation through container sidewall. This result indicates that incorporation of such paper containers in the PIP production system may help neutralize the disadvantage of biocontainers to use more water.

The decomposition of biodegradable containers has been considered to be influenced by various factors such as plant species, irrigation practices, and container wall material (Candido et al., 2008; Evans and Karcher, 2004; Evans et al., 2010). The interaction between pot decomposition and plant species is species- and pot-typedependent, which might be attributed to root growth (Evans and Karcher, 2004). After 2 years of production, river birch plants grew more vigorously and were bigger in size at Mississippi than those at Texas. Pot penetration in Mississippi by the end of the second growing season was severe. Therefore, under hand irrigation and drip irrigation systems than under ebb-and-flood irrigation system. A drip irrigation system based on substrate moisture sensors not only helps to reduce water use in production but also may help to extend longevity of the paper containers. Extended longevity, on the other hand, can potentially increase feasibility of paper containers in nursery production since pot persistence has been a major concern for production of longterm crops.

Ruter (1993) reported that substrate temperature in the PIP system was lower than that in conventional container production system measured between 1600 to $1700 \mathrm{HR}$. Though there was no control in aboveground container temperature in this study, substrate temperature change in the production pot was alleviated by the PIP production system, with lower daily maximum and higher daily minimum temperatures than environmental temperatures. Studies showed that container color had an effect on substrate temperature, with substrate temperature in container center averaged 3.5 to 3.8 ${ }^{\circ} \mathrm{C}$ higher in black containers than in white containers, resulting in less root growth (Price et al., 2011). In an aboveground nursery system, black plastic containers showed around 6 to $9{ }^{\circ} \mathrm{C}$ higher substrate temperature compared with wood pulp (paper) containers (Nambuthiri et al., 2015b). However, there was no significant difference in daily maximum, minimum, or average temperature among container types in this study, which was probably attributed to the inground placement of the production pot in the PIP system.

In summary, the tested paper biocontainers in this study did not have a negative effect on plant growth of river birch or increase in water use. Root penetration and broken bottoms or lower parts of the sidewalls of biocontainers were found at the end of the second growing season, suggesting that both biocontainers we tested may not be suitable for long-term (2 years or more) PIP production. However, there might be potential for them to be used as alternatives to plastic containers for short-term ( 1 year) production in the PIP system, considering irrigation is well controlled to reduce the period 
of pots being wet with plant species of less vigorous root growth.

\section{Literature cited}

Beeks, S.A. and M.R. Evans. 2013a. Growth of cyclamen in biocontainers on an ebb-and-flood subirrigation system. HortTechnology 23:173-176.

Beeks, S.A. and M.R. Evans. 2013b. Physical properties of biocontainers used to grow long-term greenhouse crop in an ebb-and-flood irrigation system. HortScience 48:732-737.

Candido, V., D. Castronuovo, C. Manera, and V. Miccolis. 2008. Poinsettia (Euphorbia pulcherrima) cultivation in biodegradable pots: Mechanical and agronomical behavior of pots and plant traits. Acta Hort. 801:1563-1570.

Evans, M.R. and D.L. Hensley. 2004. Plant growth in plastic, peat, and processed poultry feather fiber growing containers. HortScience 39:1012-1014.

Evans, M.R. and D. Karcher. 2004. Properties of plastic, peat, and processed poultry feather fiber growing containers. HortScience 39:1008-1011.

Evans, M.R., M. Taylor, and J. Kuehny. 2010. Physical properties of biocontainers for greenhouse crops production. HortTechnology 20:549-555.

Gilman, E.F. and D.G. Watson. 1993. Betula nigra river birch. U.S. Dept. Agr., U.S. For. Serv. Fact Sheet ST-94.

Hall, C.R., B.J. Campbell, B.K. Behe, C. Yue, R.G. Lopez, and J.H. Dennis. 2010. The appeal of biodegradable packaging to floral consumers. HortScience 45:583-591.
Hall, T.J., J.H. Dennis, R.G. Lopez, and M.I. Marshall. 2009. Factors affecting grower's willingness to adopt sustainable floriculture practices. HortScience 44:1346-1351.

Koeser, A., G. Kling, C. Miller, and D. Warnock. 2013a. Compatibility of biocontainers in commercial greenhouse crop production. HortTechnology 23:149-156.

Koeser, A., S.T. Lovell, M. Evans, and J.R. Stewart. 2013b. Biocontainer water use in short-term greenhouse crop production. HortTechnology 23:215-219.

Kuehny, J.S., M. Taylor, and M.R. Evans. 2011. Greenhouse and landscape performance of bedding plants in biocontainers. HortTechnology 21:155-161.

Levitan, L. and A. Barros. 2003. Recycling agricultural plastics in New York State. Environmental Risk Analysis Program. Cornell Center for the Environment, Ithaca, NY.

Lopez, R.G. and D.M. Camberato. 2011. Growth and development of 'Eckespoint Classic Red' poinsettia in biodegradable and compostable containers. HortTechnology 21:419-423.

Nambuthiri, S., A. Fulcher, A. Koeser, R. Geneve, and G. Niu. 2015a. Moving toward sustainability with alternative containers for greenhouse and nursery crop production: A review and research update. HortTechnology 25:8-16.

Nambuthiri, S., R.L. Geneve, T. Fernandez, G. Bi, G. Niu, and X. Wang. 2015b. Substrate temperature in plastic and alternative nursery containers. HortTechnology 25:50-56.
Price, J.G., S.A. Watts, A.N. Wright, R.W. Peters, and J.T. Kirby. 2011. Irrigation lowers substrate temperature and enhances survival of plants on green roofs in the southeastern United States. HortTechnology 21:586-592.

Ruter, J.M. 1993. Growth and landscape performance of three landscape plants produced in conventional and pot-in-pot production systems. J. Environ. Hort. 11:124-127.

Ruter, J.M. 1994. Evaluation of control strategies for reducing rooting-out problems in pot-in-pot production systems. J. Environ. Hort. 12:51-54.

Ruter, J.M. 1998. Pot-in-pot production and cyclic irrigation influence growth and irrigation efficiency of 'Okame' cherries. J. Environ. Hort. 16:159-162.

U.S. Department of Agriculture. 2012. USDA Plant hardiness zone map. 2 Sept. 2014. <http://planthardiness.ars.usda.gov/ PHZMWeb/Default.aspx $>$.

Wang, X., R.T. Fernandez, B.M. Cregg, R. Auras, A. Fulcher, G. Niu, Y. Sun, G. Bi, S. Nambuthiri, and R.L. Geneve. 2015. Multistate evaluation of plant growth and water use in plastic and alternative nursery containers. HortTechnology 25:42-49.

White, J.D. 2009. Container ecology. Growertalks 72:60-63.

Zhu, H., C.R. Krause, R.H. Zondag, R.D. Brazee, R.C. Derksen, M.E. Reding, and N.R. Fausey. 2005. A new system to monitor water and nutrient use in pot-inpot nursery production system. J. Environ. Hort. 23:47-53. 